Jurnal Kesehatan Reproduksi, 11(2), 2020:115 - 124

DOI: $10.22435 /$ kespro.v11i2.3870.115-124

\title{
HUBUNGAN STATUS EKONOMI TERHADAP PERNIKAHAN DINI PADA PEREMPUAN DI PERDESAAN INDONESIA
}

\author{
The association of socioeconomic status on early marriage \\ among women in Rural Indonesia \\ Ratna Dwi Wulandari ${ }^{1}$, Agung Dwi Laksono ${ }^{2 *}$ \\ ${ }^{1}$ Fakultas Kesehatan Masyarakat, Universitas Airlangga, Surabaya Indonesia \\ ${ }^{2}$ Badan Penelitian dan Pengembangan Kesehatan, Kementerian Kesehatan RI, Jakarta Indonesia \\ *Email: agung_dwilaksono@yahoo.co.id
}

Naskah masuk 24 September 2020; review 28 September 2020; disetujui terbit 29 Desember 2020

\begin{abstract}
Background: Early marriage practice in Indonesia is more often found in rural than in urban areas.

Objective: The aim of this study is to examine the relationship of socioeconomic status and early marriage in rural areas in Indonesia.

Method: This study used data from the 2017 Indonesian Demographic Health Survey. The sample was 2,252 of women aged 19-24 living in rural Indonesia. The variables included in the analysis were early marriage status, socioeconomic status, educational level, and working status. Analysis of collinearity, chi-square, and multiple logistic regressions were conducted in this study.

Results: The socioeconomic status and educational level were significantly associated with early marriage among women aged 19 - 24 in rural Indonesia. The poorest socioeconomic women were 2.23 times more likely to experience early marriage than the richest women. Poorer women were 1.68 times more likely to experience early marriage than the richest women. Women who did not go to school, having primary to secondary level of education were more likely to experience early marriage than those having tertiary level, constituting for 10.34 times, 12.10 times and 4.52 times, respectively. Educational level was more dominant in relation to early marriage than socioeconomic status.

Conclusion: Socioeconomic status and educational level are associated with early marriage. Poor young women with low educational level in rural areas should be the focus of the program target to reduce the coverage of early marriage in Indonesia.
\end{abstract}

Keywords: rural area, women, early marriage, socioeconomic.

\begin{abstract}
Abstrak
Latar belakang: Praktik pernikahan dini di Indonesia lebih sering ditemukan di wilayah perdesaan dibandingkan perkotaan.

Tujuan: Studi ini bertujuan untuk menganalisis hubungan status sosioekonomi terhadap kejadian pernikahan dini di perdesaan di Indonesia.

Metode: Studi ini menggunakan data Survei Demografi Kesehatan Indonesia tahun 2017. Sampel yaitu 2.252 perempuan 19-24 tahun yang tinggal di perdesaan Indonesia. Variabel yang dianalisis meliputi pernikahan dini, status sosioekonomi, tingkat pendidikan, dan status bekerja. Analisis yang digunakan yaitu uji collinearity, chisquare, dan regresi logistik ganda.

Hasil: Status sosioekonomi dan tingkat pendidikan berhubungan secara signifikan dengan pernikahan dini pada perempuan 19 - 24 tahun di perdesaan Indonesia. Perempuan paling miskin memiliki kemungkinan lebih tinggi 2,23 kali untuk mengalami pernikahan dini dibandingkan perempuan paling kaya. Perempuan miskin memiliki kemungkinan lebih tinggi 1,68 kali mengalami pernikahan dini dibandingkan perempuan paling kaya. Perempuan yang tidak sekolah, pendidikan SD-SLTP, dan SLTA memiliki kemungkinan lebih tinggi mengalami pernikahan dini dibandingkan lulusan perguruan tinggi, berturut-turut sebesar 10,34 kali, 12,10 kali, dan 4,52 kali. Faktor tingkat pendidikan lebih dominan hubungannya dengan pernikahan dini dibandingkankan dengan faktor status sosioekonomi.

Kesimpulan: Status sosioekonomi dan tingkat pendidikan berhubungan dengan pernikahan dini. Remaja putri miskin dengan tingkat pendidikan rendah di perdesaan harus menjadi fokus sasaran program penurunan cakupan pernikahan dini di Indonesia.
\end{abstract}

Kata Kunci: perdesaan, perempuan, pernikahan dini, sosioekonomi. 


\section{PENDAHULUAN}

Pernikahan dini adalah sebuah pernikahan yang dilakukan sebelum umur 19 tahun. Batasan umur ini merujuk pada Undang-Undang 16 Tahun 2019 tentang Perubahan atas UndangUndang Nomor 1 Tahun 1974 tentang Perkawinan. Pernikahan dini merupakan masalah global yang masih ditemukan di berbagai negara berkembang, termasuk Indonesia, ${ }^{1,2}$ khususnya di kawasan Timur Indonesia. ${ }^{3}$ Studi sebelumnya menunjukkan bahwa rata-rata umur pernikahan dini di Kosovor-Albania adalah 17,3 tahun, sementara di Barat Laut Ethiopia adalah 17 tahun. ${ }^{4,5}$ Hasil Survei Demografi Kesehatan Indonesia (SDKI) tahun 2012 menunjukkan bahwa diperkirakan 17 persen anak perempuan menikah di usia kurang dari 18 tahun di Indonesia. Selanjutnya SDKI tahun 2017 melaporkan terjadinya perubahan tren pernikahan yaitu 63,7 persen anak perempuan Indonesia menikah pada usia 20 tahun. ${ }^{6,7}$

Beberapa penelitian telah melaporkan adanya dampak negatif yang diakibatkan oleh pernikahan dini, seperti masalah kesehatan reproduksi dan kejadian kekerasan pada perempuan. Pernikahan dini yang terkait dengan masalah kesehatan reproduksi yaitu ketidaksiapan organ reproduksi, kehamilan yang tidak diinginkan, praktik aborsi yang tidak aman, dan bahkan kematian ibu. ${ }^{8-10}$ Berbagai penelitian juga menunjukkan bahwa kejadian kekerasan pada perempuan lebih tinggi terjadi pada perempuan dengan umur yang lebih muda. ${ }^{11-13}$ Studi di Mesir melaporkan bahwa perempuan yang menikah pada umur $<18$ tahun memiliki peluang lebih tinggi 1,16 kali mengalami kekerasan fisik dan 2,38 kali, untuk mengalami kekerasan seksual dibandingkan

\footnotetext{
* Korespondensi:

(agung_dwilaksono@yahoo.co.id)

(C) Badan Penelitian dan Pengembangan Kesehatan ISSN: 2354-8762 (elektronik); ISSN: 2087-703X (cetak)
}

dengan perempuan yang menikah pada umur 18 tahun ke atas. ${ }^{14}$

Lebih jauh lagi, pernikahan dini juga berdampak buruk pada status kesehatan anak. Pasangan yang mengalami pernikahan dini berhubungan dengan berat badan lahir anak yang rendah hingga kematian anak. ${ }^{15,16}$ Sementara itu studi lain di Malaysia juga melaporkan keterkaitan antara pernikahan dini di wilayah tersebut dengan kelahiran prematur dan bayi berat lahir rendah. ${ }^{8}$ Pernikahan dini seringkali terjadi karena rendahnya status sosioekonomi keluarga, ${ }^{17,18}$ sehingga dianggap menjadi salah satu solusi untuk lepas dari kesulitan ekonomi, terutama bagi keluarga perempuan. Harapan bagi keluarga tidak hanya untuk melepaskan beban ekonomi dari satu anggota keluarga, tapi lebih jauh anak perempuan yang sudah menikah diharapkan dapat membantu perekonomian keluarga. ${ }^{2,3}$

Penelitian sebelumnya menemukan bahwa praktik pernikahan dini lebih sering terjadi di wilayah perdesaan dibanding perkotaan. ${ }^{19}$ Jika dibandingkan dengan perkotaan, praktik pernikahan di perdesaan sangat kental dengan unsur budaya yang lebih permisif terhadap pernikahan dini. Perempuan perdesaan yang umurnya sudah mendekati 20 tahunan namun belum menikah akan dianggap sebagai perawan tua. ${ }^{20}$ Tinggal di perdesaan juga identik dengan adanya keterbatasan akses ke pelayanan kesehatan dan informasi tentang kesehatan, ${ }^{21}$ termasuk informasi kesehatan reproduksi remaja. Kesehatan reproduksi remaja seringkali dikaitkan dengan kehamilan yang tidak diinginkan, aborsi, penyakit menular seksual, dan layanan kesehatan reproduksi. ${ }^{15,22}$ Oleh karena itu, studi ini bertujuan untuk menganalisis hubungan status sosioekonomi terhadap kejadian pernikahan dini di wilayah perdesaan Indonesia. 


\section{METODE}

Studi ini menggunakan data sekunder dari Survei Demografi dan Kesehatan Indonesia (SDKI) tahun 2017. Pengambilan sampel dilakukan dengan menggunakan metode stratification and multistage random sampling. Unit analisis dalam studi ini adalah perempuan menikah berumur 19-24 tahun. Pemilihan unit analisis dengan kategori umur dimulai dari 19 tahun dimaksudkan agar sudah diketahui dengan pasti status pernikahan dini responden, apakah menikah sebelum umur 19 tahun atau setelah umur 19 tahun. Sedangkan kategori umur 19 - 24 tahun diasumsikan bahwa pada rentang umur tersebut belum ada perubahan yang berarti pada karakteristik demografi responden. Definisi wilayah perdesaan mengacu pada kriteria yang ditetapkan oleh Badan Pusat Statistik melalui Peraturan Kepala Badan Pusat Statistik Nomor 37 Tahun 2010 tentang Klasifikasi Perkotaan dan Perdesaan di Indonesia. ${ }^{23}$ Berdasarkan unit analisis tersebut maka diperoleh 2.252 responden yang dianalisis dalam studi ini.

Variabel dependen dalam studi ini adalah pernikahan dini responden. Pengertian pernikahan dini dalam studi ini merujuk pada Undang-Undang (UU) Nomor 16 Tahun 2019 tentang Perubahan Atas UU Nomor 1 Tahun 1974 tentang Perkawinan, yaitu pernikahan yang dilakukan sebelum umur 19 tahun. ${ }^{24}$ Tiga variabel independen yang dianalisis dalam studi ini, yaitu status sosioekonomi, tingkat pendidikan, dan status bekerja responden.

Status sosioekonomi responden ditentukan berdasarkan pada kuintil kekayaan yang dinilai dari kepemilikan barang di rumah tangga, seperti televisi, sepeda, mobil dan karakteristik rumah seperti sumber air minum, fasilitas toilet, dan bahan bangunan utama untuk lantai rumah. Skor ini dihitung dengan menggunakan analisis komponen utama. Kuintil kekayaan secara nasional disusun berdasarkan skor rumah tangga untuk setiap orang dalam rumah tangga dan kemudian dibagi dengan distribusi ke dalam lima kategori yang sama, dengan masing-masing menyumbang 20 persen dari populasi. $^{25,26}$
Tingkat pendidikan adalah pengakuan responden atas kepemilikan ijazah pendidikan terakhir yang telah ditamatkan. Tingkat pendidikan dibagi menjadi empat kategori, yaitu tidak sekolah, SD-SLTP, SLTA, dan Perguruan Tinggi. Status bekerja adalah pengakuan responden dalam bekerja, dibagi dalam dua kategori, yaitu tidak bekerja dan bekerja.

Tahap awal analisis yaitu melakukan uji collinearity untuk memastikan tidak adanya korelasi yang kuat antar variabel independen. Selanjutnya dilakukan analisis bivariat dengan uji chi-square untuk melihat hubungan antara status pernikahan dini dengan seluruh variabel lain yang dianalisis. Tahap akhir dilakukan analisis multivariat dengan menggunakan uji regresi logistik ganda. Analisis statistik dilakukan dengan menggunakan perangkat lunak SPSS-21.

SDKI tahun 2017 telah mendapatkan persetujuan etik dari Komite Etik Penelitian Kesehatan Badan Penelitian dan Pengembangan Kesehatan, Kementerian Kesehatan RI. Sampel telah mendapatkan penjelasan dan menandatangani formulir persetujuan untuk berpartisipasi dalam SDKI 2017. Penggunaan Data SDKI tahun 2017 untuk studi ini telah mendapatkan ijin dari ICF International melalui laman: https://dhsprogram.com/data/new-userregistration.cfm.

\section{HASIL PENELITIAN}

Sebanyak 2.252 responden dalam studi ini merupakan perempuan menikah berumur 19 24 tahun di wilayah perdesaan Indonesia. Tabel 1 menampilkan hasil uji collinearity seluruh variabel independen yang diuji. Hasil uji ini menunjukan bahwa tidak ada korelasi yang kuat antar variabel independen, yaitu status sosioekonomi, tingkat pendidikan, dan status bekerja. Nilai toleransi seluruh variabel, independen ini lebih besar dari 0,10. Sementara nilai variance inflation factor (VIF) untuk semua variabel independen kurang dari 10,00. Dari hasil uji ini dapat disimpulkan bahwa tidak terdapat multicollinearity antar variabel independen pada model regresi ini. 
Tabel 1. Hasil uji collinearity antar variabel independen $(n=2.252)$

\begin{tabular}{lcc}
\hline \multirow{2}{*}{\multicolumn{1}{c}{ Variabel }} & \multicolumn{2}{c}{ Statistik collinearity } \\
\cline { 2 - 3 } & Toleransi & VIF \\
\hline Status sosioekonomi & 0,932 & 1,073 \\
Tingkat pendidikan & 0,934 & 1,071 \\
Status bekerja & 0,998 & 1,002 \\
\hline
\end{tabular}

Karakteristik responden diperoleh dari hasil uji chi-square antara status pernikahan dini dengan status sosioekonomi, tingkat pendidikan, dan status bekerja (Tabel 2). Pernikahan secara signifikan berhubungan dengan status sosiekonomi dan tingkat pendidikan. Pernikahan dini didominasi oleh responden dengan status sosioekonomi paling miskin,
$(41,3 \%)$ dan proporsinya semakin menurun seiring dengan meningkatnya status sosioekonomi responden, yaitu 6,1 persen pada responden dengan sosioekonomi paling kaya. Sedangkan berdasarkan tingkat pendidikan dan status bekerja, pernikahan didominasi oleh pendidikan SLTA dan status tidak bekerja, yaitu berturut-turut sebesar 41,3 persen, 67,5 persen, dan 66,9 persen.

Tabel 2. Karakteristik Responden $(n=2.252)$

\begin{tabular}{|c|c|c|c|c|c|}
\hline \multirow{3}{*}{ Karakteristik Responden } & \multicolumn{4}{|c|}{ Status Pernikahan Dini } & \multirow{3}{*}{$P$-value } \\
\hline & \multicolumn{2}{|c|}{ Tidak } & \multicolumn{2}{|c|}{$\mathbf{Y a}$} & \\
\hline & $\mathbf{n}$ & $\%$ & $\mathbf{n}$ & $\%$ & \\
\hline Status sosioekonomi & & & & & $<0,001$ \\
\hline Paling miskin & 334 & 24,9 & 1.017 & 41,3 & \\
\hline Miskin & 287 & 21,4 & 602 & 24,5 & \\
\hline Menengah & 298 & 22,2 & 428 & 17,4 & \\
\hline Kaya & 260 & 19,4 & 266 & 10,8 & \\
\hline Paling kaya & 162 & 12,1 & 149 & 6,1 & \\
\hline Tingkat pendidikan & & & & & $<0,001$ \\
\hline Tidak sekolah & 8 & 0,6 & 44 & 1,8 & \\
\hline SD-SLTP & 138 & 10,3 & 694 & 28,2 & \\
\hline SLTA & 1.010 & 75,3 & 1.662 & 67,5 & \\
\hline Perguruan Tinggi & 185 & 13,8 & 62 & 2,5 & \\
\hline Status bekerja & & & & & 0,392 \\
\hline Tidak bekerja & 915 & 68,2 & 1.645 & 66,9 & \\
\hline Bekerja & 426 & 31,8 & 815 & 33,1 & \\
\hline
\end{tabular}

Uji chi-square, signifikan pada $\mathrm{p}<0,05$

Selanjutnya dilakukan uji regresi logistik ganda untuk menentukan hubungan antara variabel independen dengan status pernikahan dini pada perempuan $19-24$ tahun di perdesaan Indonesia. Prediktor yang terlibat dalam analisis ini yaitu variabel status sosioekonomi dan tingkat pendidikan. Status bekerja tidak dimasukkan dalam analisis multivariat karena hasil analisis tidak menunjukkan hasil yang signifikan pada tahap analisis bivariat. Pada variabel dependen, referensi (ref) yang dipilih yaitu "tidak mengalami pernikahan dini" sedangkan pada variabel independen yang dipilih sebagai referensi (ref) yaitu status sosioekonomi paling kaya dan tingkat pendidikan perguruan tinggi. 
Tabel 3. Hubungan antara variabel independen dengan pernikahan dini $(n=2.252)$

\begin{tabular}{lccc}
\hline & Odds Ratio (OR) & $\mathbf{9 5 \%}$ CI & $P$-value \\
\hline Sosioekonomi paling miskin & 2,23 & $1,70-2,92$ & $<0,001$ \\
Sosioekonomi miskin & 1,68 & $1,28-2,22$ & $<0,001$ \\
Sosioekonomi menengah & 1,20 & $0,91-1,59$ & 0,205 \\
Sosioekonomi kaya & 0,93 & $0,69-1,24$ & 0,602 \\
Sosioekonomi paling kaya & Ref & & \\
Pendidikan tidak sekolah & 10,34 & $4,58-23,33$ & $<0,001$ \\
Pendidikan SD-SLTP & 12,10 & $8,55-17,13$ & $<0,001$ \\
Pendidikan SLTA & 4,52 & $3,34-6,12$ & $<0,001$ \\
Pendidikaan perguruan tinggi & Ref & & \\
\hline
\end{tabular}

Uji regresi logistik ganda, $\mathrm{CI}=$ confidence interval; signifikan pada $\mathrm{p}<0,05$

Tabel 3 menunjukkan bahwa perempuan 19 24 tahun dengan status sosioekonomi paling miskin memiliki kemungkinan lebih tinggi 2,23 kali untuk mengalami pernikahan dini dibandingkan dengan perempuan $19-24$ tahun paling kaya (OR 2,23; 95\%CI: 1,70-2,92). Perempuan 19 - 24 tahun miskin memiliki kemungkinan lebih tinggi 1,68 kali untuk mengalami pernikahan dini dibandingkan dengan perempuan 19-24 tahun paling kaya (OR 1,68; 95\%CI: 1,28-2,22). Sementara perempuan $19-24$ tahun dengan status sosioekonomi menengah dan kaya tidak berhubungan signifikan dengan pernikahan dini. Hasil studi ini menunjukkan bahwa perempuan $19-24$ tahun berstatus sosioekonomi miskin di perdesaan Indonesia memiliki kemungkinan lebih tinggi untuk mengalami pernikahan dini dibandingkan dengan perempuan $19-24$ tahun dengan status sosioekonomi lainnya.

Selain status sosioekonomi, tingkat pendidikan berhubungan signifikan dengan pernikahan dini di perdesaan di Indonesia. Perempuan $19-24$ tahun yang tidak sekolah memiliki kemungkinan lebih tinggi 10,34 kali mengalami pernikahan dini dibandingkan dengan perempuan 19-24 tahun lulusan perguruan tinggi (OR 10,34; 95\%CI: 4,58 - 2 13,33). Perempuan 19-24 tahun dengan tingkat pendidikan SD-SLTP memiliki kemungkinan lebih tinggi 12,10 kali mengalami kejadian pernikahan dini dibandingkan dengan perempuan 19 - 24 tahun lulusan perguruan tinggi (OR 12,10; 95\%CI: 8,55-17,13). Sedangkan perempuan 19-24 tahun dengan tingkat pendidikan SLTA memiliki kemungkinan lebih tinggi 4,52 kali mengalami pernikahan dini dibandingkan dengan perempuan lulusan perguruan tinggi (OR 4,52; 95\%CI: 3,34-6,12). Hasil studi ini menunjukkan bahwa perempuan 19 - 24 tahun di perdesaan Indonesia dengan tingkat pendidikan yang lebih rendah dari perguruan tinggi (tidak sekolah, SD, SLTP, dan SLTA) memiliki kemungkinan lebih tinggi mengalami pernikahan dini dibandingkan dengan lulusan perguruan tinggi. Berdasarkan nilai odds ratio (OR), faktor tingkat pendidikan lebih dominan hubungannya dengan pernikahan dini pada perempuan $19-24$ tahun di perdesaan Indonesia dibandingkankan dengan faktor status sosioekonomi. 


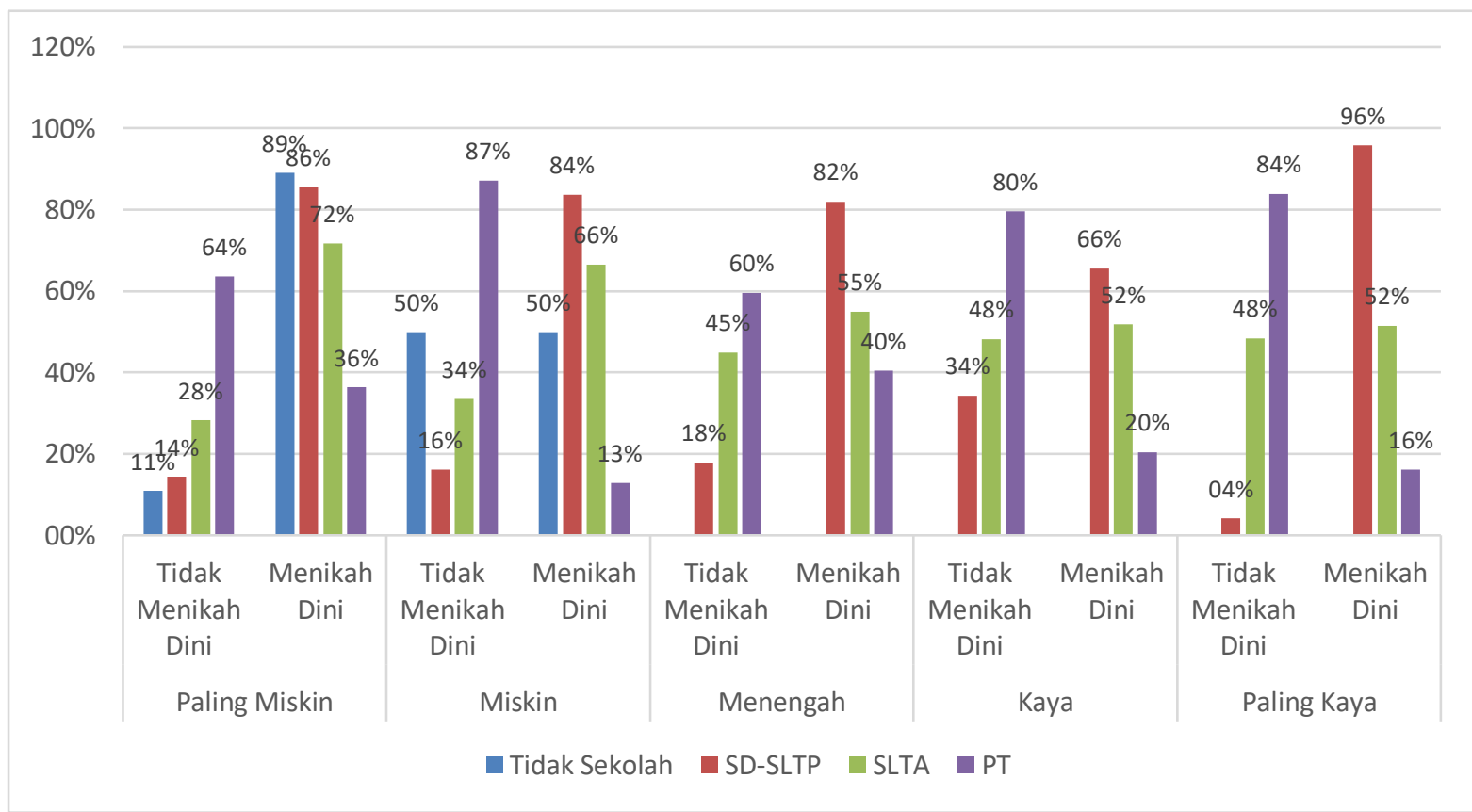

\section{Gambar 1. Diagram interaksi antara status pernikahan dini, status sosioekonomi, dan tingkat pendidikan perempuan 19 - 24 tahun di perdesaan Indonesia}

Gambar 1 mempresentasikan interaksi antara tiga variabel studi, yaitu status pernikahan dini, status sosioekonomi, dan tingkat pendidikan. Perempuan perempuan $19-24$ tahun di perdesaan Indonesia yang mengalami pernikahan dini pada semua status sosioekonomi, didominasi oleh perempuan dengan tingkat pendidikan yang rendah.

\section{PEMBAHASAN}

Hasil analisis menemukan bahwa status sosioekonomi berhubungan dengan kejadian pernikahan dini pada perempuan umur $19-24$ tahun yang tinggal di perdesaan Indonesia. Kemiskinan merupakan faktor risiko pada perempuan di wilayah perdesaan Indonesia untuk mengalami kejadian pernikahan dini. Beberapa penelitian sebelumnya juga menemukan informasi yang serupa, yaitu kemiskinan menjadi faktor risiko dari terjadinya pernikahan dini, terutama di wilayah perdesan. Studi sebelumnya menunjukkan bahwa kemiskinan merupakan faktor utama yang memaksa para gadis muda di perdesaan untuk melakukan pernikahan dini dan praktik ini umum terjadi di negara berkembang, seperti India, Iran, dan Indonesia. ${ }^{27-29}$

Pernikahan dini menjadi solusi untuk keluar dari kemiskinan bagi para orang tua yang memiliki anak perempuan. Menikahkan salah satu anak perempuan yang dimiliki menjadi jalan keluar paling praktis untuk mengurangi tekanan beban ekonomi keluarga. ${ }^{2}$ Pengaruh status ekonomi terhadap terjadinya pernikahan dini juga berkaitan erat dengan nilai anak secara ekonomi bagi orang tua. Beberapa suku asli Indonesia diketahui menganggap bahwa anak perempuan adalah aset. Nilai anak secara ekonomi ini berkaitan dengan tingginya mahar yang disyaratkan saat ada laki-laki yang akan meminang anak perempuannya tersebut. Hal ini dapat dilihat pada suku Lani di Kabupaten Lani Jaya dan suku Muyu di Boven Digoel, Papua, permintaan tukon atau yang biasa disebut mahar pernikahan bisa bernilai hingga ratusan juta rupiah, dalam bentuk puluhan ekor babi atau sebuah rumah batu. ${ }^{30-32}$ 
Selain status sosioekonomi, studi ini juga menunjukkan bahwa tingkat pendidikan secara signifikan berhubungan dengan kejadian pernikahan dini pada perempuan $19-24$ tahun di perdesaan Indonesia. Semakin rendah tingkat pendidikan seorang perempuan, semakin tinggi risiko perempuan tersebut untuk mengalami kejadian pernikahan dini. Hasil penelitian di Situbondo Jawa Timur dan dua studi di Bangladesh dan Iran menemukan hal yang serupa dengan studi ini. Ketiga studi tersebut menginformasikan bahwa remaja putri dengan tingkat pendidikan yang rendah secara signifikan mengalami pernikahan dini. ${ }^{1,33,34}$ Pendidikan yang lebih baik membuat seorang perempuan menjadi lebih paham tentang apa yang menjadi kebutuhannya. Tingkat pendidikan juga berkaitan dengan kemampuan individu perempuan untuk memahami risiko dan konsekuensi atas setiap sikap dan perbuatan yang diambil. ${ }^{35}$

Status sosioekonomi dan tingkat pendidikan seringkali ditemukan secara beriringan memengaruhi kinerja di bidang kesehatan. Seseorang dengan status sosioekonomi yang baik seringkali juga berpendidikan tinggi sehingga memiliki output kesehatan yang baik. ${ }^{36-38}$ Sementara status sosioekonomi dan tingkat pendidikan yang rendah seringkali ditemukan sebagai hambatan untuk mencapai output kesehatan yang berkualitas. ${ }^{39,40}$ Sebuah penelitian yang dilakukan di Indramayu Jawa Barat menegaskan fenomena tersebut. Studi tersebut menunjukkan bahwa pernikahan dini berhubungan dengan tingkat pendidikan dan status kekayaan keluarga. ${ }^{3}$

Pernikahan dini lebih sering terjadi di wilayah perdesaan. ${ }^{20}$ Kondisi ini berhubungan dengan masih kentalnya sistem sosial patriarkal di wilayah perdesaan ${ }^{41}$ yang memberi peluang lebih besar bagi laki-laki untuk berkembang, termasuk kesempatan untuk menempuh pendidikan yang lebih baik. ${ }^{42}$ Situasi yang demikian turut memarakkan kejadian dan praktik pernikahan dini di wilayah perdesaan di Indonesia.

\section{Keterbatasan studi}

Studi ini memiliki keterbatasan. Pelaksanaan studi dilakukan dengan pendekatan kuantitatif sehingga menampilkan fenomena secara superfisial. Beberapa fenomena tentang norma sosial budaya dan agama yang diketahui sebelumnya bisa mempengaruhi terjadinya pernikahan dini tidak dapat diungkap dalam studi ini. ${ }^{20,43}$

\section{KESIMPULAN}

Berdasarkan hasil analisis dapat disimpulkan bahwa status sosioekonomi dan tingkat pendidikan perempuan $19-24$ tahun di perdesaan Indonesia berhubungan dengan terjadinya pernikahan dini. Semakin baik tingkat sosioekonomi maka semakin kecil kemungkinan untuk mengalami pernikahan dini di wilayah perdesaan. Perempuan tidak sekolah dan berpendidikan SD, SLTP, dan SLTA memiliki kemungkinan lebih tinggi untuk mengalami pernikahan dini dibandingkan dengan lulusan perguruan tinggi. Faktor tingkat pendidikan lebih dominan dibandingkan dengan faktor status sosioekonomi dalam hubungannya dengan kejadian pernikahan dini di wilayah perdesaan Indonesia.

\section{SARAN}

Informasi hasil penelitian ini penting sebagai dasar bagi pengembangan kebijakan perlindungan kesehatan reproduksi remaja untuk mengurangi pernikahan dini di wilayah perdesaan Indonesia. hal ini terutama untuk mengembangkan program pemberdayaan remaja putri dan upaya membebaskan mereka dari kemiskinan di wilayah perdesaan. Hasil studi ini merekomendasikan pemerintah untuk menetapkan sasaran yang fokus pada remaja putri yang miskin dan memiliki tingkat pendidikan rendah di wilayah perdesaan pada program kebijakan penurunan cakupan pernikahan dini di wilayah perdesaan di Indonesia, terutama pada wilayah atau suku dengan persentase kejadian pernikahan dini yang tinggi. Selain itu diperlukan studi lebih lanjut dengan pendekatan kualitatif agar bisa mengungkap fenomena terkait norma sosial budaya dan agama dalam memengaruhi terjadinya pernikahan dini di wilayah perdesaan di Indonesia. 


\section{UCAPAN TERIMA KASIH}

Penulis mengucapkan terima kasih kepada Inner City Fund (ICF) International yang telah memberikan ijin pemanfaatan data SDKI 2017 ini.

\section{DAFTAR PUSTAKA}

1. Kamal SMM, Hassan CHEH, Alam GM, Ying Y. Trends and Determinants Child Marriage in Bangladesh. J Biosoc Sci. 2015;47(01):120-39.

2. Singh R, Vennam U. Factors Shaping Trajectories to Early marriage: Evidence from Young Lives, India. Young Lives Working Paper 149. 2016.

3. Muharry A, Hakimi M, Wahyuni B. Family Structure and Early Marriage on Women in Indramayu Regency. J Kesehat Masy. 2018;13(3):314-22.

4. Hyseni Duraku Z, Jemini-Gashi L, Author, Toçi E. Perceptions of Early Marriage, Educational Aspirations, and Career Goals among Kosovar Adolescents. Marriage Fam Rev. 2020;56(6):513-34.

5. Bezie M, Addisu D. Determinants of early marriage among married women in Injibara town, north West Ethiopia: Communitybased cross-sectional study. BMC Womens Health. 2019;19(1):Article number 134.

6. Statistics Indonesia (Badan Pusat Statistik-BPS) National Population and Family Planning Board (BKKBN) and Kementerian Kesehatan (Kemenkes$\mathrm{MOH}$ ) and ICF International. Demographic Health Survey 2012. Statistics Indonesia (Badan Pusat Statistik-BPS) National Population and Family Planning Board $(\mathrm{BKKBN})$ and Kementerian Kesehatan (Kemenkes- $\mathrm{MOH}$ ) and ICF International. Jakarta; 2013.

7. ICF SI (Badan PSNP and FPB (BKKBN) and $\mathrm{KK}$ (Kemenkes-MOH) and. Indonesia Demographic and Health Survey. Statistics Indonesia (Badan Pusat Statistik-BPS) National Population and Family Planning Board (BKKBN) and
Ministry of Health of Republic of Indonesia (Kemenkes- $\mathrm{MOH}$ ) and ICF International. Jakarta; 2017.

8. Kohno A, Dahlui M, Daliana N, Farid N, Safii R, Nakayama T. Why girls get married early in Sarawak, Malaysia - an exploratory qualitative study. BMC Womens Health. 2020;1-13.

9. Maniar S, Putu B, Novelina A, Praba K, Rachmawati D, Stis S, et al. Determinants of early marriage among female adolescent in Indonesia. Int $\mathrm{J}$ Adolesc Med Health. 2018;1-6.

10. Talukder A, Hasan MM, Razu SR, Hossain MZ. Early marriage in Bangladesh: A cross-sectional study exploring the associated factors. J Int Womens Stud. 2020;21(1):68-78.

11. Zheng B, Zhu X, Hu Z, Zhou W, Yu Y, Yin $S$, et al. The prevalence of domestic violence and its association with family factors: A cross-sectional study among pregnant women in urban communities of Hengyang City, China. BMC Public Health. 2020;20(1):Article number 620.

12. Dhar D, McDougal L, Hay K, Atmavilas $\mathrm{Y}$, Silverman J, Triplett D, et al. Associations between intimate partner violence and reproductive and maternal health outcomes in Bihar, India: A cross-sectional study. Reprod Health. 2018;15(1):1-14.

13. Putra IGNE, Pradnyani PE, Parwangsa NWPL. Vulnerability to domestic physical violence among married women in Indonesia. J Heal Res. 2019;33(2):90-105.

14. El-Gazzar AF, Aziz MM, Mohammed HM, Elgibaly O, Darwish MM. Spousal violence and its determinants among married adolescent girls in Upper Egypt. J Egypt Public Health Assoc. 2020;95(1):Article number 28.

15. Tri Wahyudi, Mubasysyir Hasanbasri, Hari Kusnanto MH. Social Determinants of Health of Child Marriage (Analysis of IFLS 2000,2007, 2014). J Kesehat Masy. 2019;15(1):62-8.

16. Siti LN, Isnaini N, Syafitri M. (The relationship of low birth weight babies (LBW) with neonatal mortality in RSUD 
dr. H. Abdul Moeloek Bandar Lampung in 2013) Hubungan bayi berat lahir rendah (BBLR) dengan kematian neonatal di RSUD dr. H. Abdul Moeloek Bandar Lampung Tahun 2013. J Kebidanan. 2015;1(3):116-20.

17. Ahmed S, Khan A, Khan S, Noushad S. Early Marriage;A Root of Current Physiological and Psychosocial Health Burdens. Int J Endorsing Heal Sci Res. 2014;2(1):50.

18. Montazeri S, Gharacheh M, Mohammadi N, Rad JA, Ardabili HE. Determinants of Early Marriage from Married Girls , Perspectives in Iranian Setting: A Qualitative Study. J Environ Public Health. 2016;2016.

19. Pandya YP, Bhanderi DJ. An epidemiological study of child marriages in a rural community of Gujarat. Indian $\mathrm{J}$ Community Med. 2015;40(4):246-51.

20. Imanugraha, S. H, Budisuari MA. Aiming for Bella Ends Early Marriage (Mengincar Si Bella Berujung Pernikahan Dini). Surabaya: Unesa University Press; 2016.

21. Laksono AD, Wulandari RD. Urban-Rural Disparities of Facility-Based Childbirth in Indonesia. In: 4th International Symposium on Health Research (ISHR 2019) [Internet]. Denpasar: Atlantis Press; 2020. p. 33-9. Available from: https://www.atlantispress.com/proceedings/ishr-19/125935017

22. Handayani OWK, Wiranti I, Raharjo BB, Nugroho E. The Reproduction Health Behavior of High School Teenagers in Semarang, Indonesia. Open Public Health J. 2019;12(1):309-14.

23. Badan Pusat Statistik. Peraturan Kepala Badan Pusat Statistik Nomor 37 Tahun 2010 tentang Klasifikasi Perkotaan dan Perdesaan di Indonesia [Internet]. 37/2010 Indonesia; 2010. Available from: https://sirusa.bps.go.id/webadmin/doc/MF D_2010_Buku_1.pdf

24. Republik Indonesia. Undang-Undang Nomor 16 Tahun 2019 tentang Perubahan Atas UU Nomor 1 Tahun 1974 tentang Perkawinan. Undang-Undang Nomor 16 Tahun 2019 Indonesia; 2019 p. 1.

25. Wulandari RD, Putri NK, Laksono AD.
Socioeconomic Disparities in Antenatal Care Utilisation in Urban Indonesia. Int $\mathbf{J}$ Innov Creat Chang. 2020;14(2):498-514.

26. Wulandari RD, Qomarrudin MB, Supriyanto S, Laksono AD. Socioeconomic Disparities in Hospital Utilization among Elderly People in Indonesia. Indian J Public Heal Res Dev. 2019;10(11):1800-4.

27. Asna-ashary M, Farzanegan MR, Feizi M, Gholipour HF. Socio-Economic Determinants of Child Marriage : Evidence from the Iranian Provinces. CESIFO Working Papers. 2020.

28. Natanael M. J., Fajar M. R. and MR. Prevalence of Child Marriage and Its Determinants among Young Women in Indonesia. Child Poverty Soc Prot Conf. 2013;1-27.

29. Paul P. Children and Youth Services Review E ff ects of education and poverty on the prevalence of girl child marriage in India: A district - level analysis. Child Youth Serv Rev. 2019;100(January):1621.

30. Laksono AD, Wulandari RD. "Children are Assets": Meta Synthesis of Child Values in the Lani and Acehnese ("Anak adalah Aset": Meta Sintesis Nilai Anak pada Suku Lani dan Suku Aceh). J Kesehat Reproduksi. 2019;10(1):11-20.

31. Ruslan I. "Nilai Anak" dalam Perspektif Masyarakat Multi Etnik dan Agama. J Pendidik Sosiol dan Hum. 2017;8(2):1833.

32. Laksono AD, Soedirham O, Saptandari P, Wulandari RD. Study of family size among tenggerese in Indonesia. Int J Innov Creat Chang. 2020;13(4):964-78.

33. Sanjaya A, Narendra MB, Irwanto, Suryawan A, Irmawati M, Efendi F. Early marriage and its relationship with child development. Indian J Public Heal Res Dev. 2018;9(9):193-8.

34. Heidari F, Dastgiri S. The prevalence and predicting factors of female child marriage in north-west of iran: A case-control multicenter study. Gazi Med J. 2020;31(3):38792.

35. Tille F, Röttger J, Gibis B, Busse R, Kuhlmey A, Schnitzer S. Patients' 
perceptions of health system responsiveness in ambulatory care in Germany. Patient Educ Couns. 2019;102(1):162-71.

36. Megatsari H, Laksono AD, Ibad M, Herwanto YT, Sarweni KP, Geno RAP, et al. The community psychosocial burden during the COVID-19 pandemic in Indonesia. Heliyon. 2020;6(10):Article number e05136.

37. Ipa M, Widawati M, Laksono AD, Kusrini I, Dhewantara PW. Variation of preventive practices and its association with malaria infection in eastern Indonesia: Findings from community-based survey. PLoS One. 2020;15(5):e0232909.

38. Wulandari RD, Laksono AD. Education as predictor of the knowledge of pregnancy danger signs in Rural Indonesia. Int J Innov Creat Chang. 2020;13(1):1037-51.

39. Rohmah N, Yusuf A, Hargono R, Laksono $\mathrm{AD}$, Masruroh, Ibrahim I, et al. Determinants of teenage pregnancy in
Indonesia. Indian J Forensic Med Toxicol. 2020;14(3):2080-5.

40. Laksono AD, Wulandari RD. The Barrier to Maternity Care in Rural Indonesia. J Public Heal From Theory to Pract. 2020; Online First.

41. Sakina AI, A. DHS. Highlighting Patriarchal Culture in Indonesia (Menyoroti Budaya Patriarki di Indonesia). Share Soc Work J. 2017;7(1):71-80.

42. Sudarso, Keban PE, Mas'udah S. Gender, religion and patriarchy: The educational discrimination of coastal madurese women, East Java. J Int Womens Stud. 2019;20(9):1-12.

43. Ahyani S. Religious Court Considerations for Early Marriage Marriage Dispensation Due to Pregnancy Outside Marriage (Pertimbangan Pengadilan Agama Atas Dispensasi Pernikahan Usia Dini Akibat Kehamilan Di Luar Nikah). J Wawasan Huk. 2016;34(1):1-7. 